\title{
Tracking dinosaurs in Spain
}

Neil D.L. Clark

Acta Palaeontologica Polonica 60 (4), 2015: 856-856 doi:http://dx.doi.org/10.4202/app.00226.2015

Félix Pérez-Lorente 2015. Dinosaur Footprints and Trackways of La Rioja. 376 pp. Indiana University Press. Hardcover. ISBN: 978-0-253-01515-0. Price \$85.00/£61.00; e-book \$84.99.

Neil D.L. Clark [neil.clark@glasgow.ac.uk], The Hunterian, University of Glasgow, University Avenue, Glasgow G12 8QQ, UK.

This is an open-access article distributed under the terms of the Creative Commons Attribution License (for details please see creativecommons.org), which permits unrestricted use, distribution, and reproduction in any medium, provided the original author and source are credited.

FoF 